\title{
DAİMİ İŞYERİ İLE TRANSFER FIYYATLANDIRMASI İLIŞ̧KİSINE OECD MODEL VERGİ ANLAŞMASI VE BEPS BAĞLAMINDA BİR BAKIŞ
}

\author{
Yalçın ALGANER ${ }^{[*]}$ \\ Öznur YILMAZ $\left.{ }^{[* *}\right]$
}

Özet

Ekonomik faaliyetlerin sınır ötesi nitelik kazanması çok uluslu şirketler tarafından elde edilen ticari kazançların elde edildiği yerin tespitini güçleștirmekte ve çifte vergilendirme sorununun ortaya çıkmasına neden olabilmektedir. Ancak değişen ekonomik yapı, vergi matrahının aşındırılması ve kârın aktarılmasını da önemli bir sorun haline getirmektedir. Bu çalışmada daimi işyeri kavramı ile transfer fiyatlandırması arasındaki ilişki, OECD Model Vergi Anlaşması ve BEPS bağlamında ele alınmıştır.

Anahtar Kelimeler: Çifte vergilendirme, daimi işyeri, BEPS eylem planı.

JEL Sınıflaması: H25, H26, K34

\section{A VIEW ON THE RELATION BETWEEN PERMANENT ESTABLISHMENT AND TRANSFER PRICING IN THE CONTEXT OF OECD MODEL TAX CONVENTION AND BEPS}

\begin{abstract}
Having the cross-border character of economic activities makes it difficult to identify the place where multinational companies derives business profits and may give rise to problems of double taxation. However, the changin the economic structure creates an important tax base erosion and profit shifting issue. In this study, the relation between the concept of permanent establishment and transfer pricing is discussed in the context of OECD Model Tax Convention and BEPS.
\end{abstract}

Keywords: Double taxation, permanent establishment, BEPS action plan.

JEL Classification: H25, H26, K34

[*] Yrd. Doç. Dr., Marmara Üniversitesi İktisat Fakültesi Maliye Bölümü, yalcin.alganer@gmail.com

${ }^{[*}$ Marmara Üniversitesi Sosyal Bilimler Enstitüsü Maliye Anabilim Dalı Mali Hukuk Anabilim Dalı Doktora Öğrencisi, oznur.dyg.ylmz@gmail.com 


\section{Giriş}

Ülke içinde ikamet edenlerin yurtdışında ve ülke dışında ikamet edenlerin yurtiçinde vergiye tabi faaliyetlerde bulunması ve dünya ticaretinin büyük bir bölümünü oluşturan çok uluslu şirketlerin yaygınlaşması neticesinde ekonomik faaliyetlerin bir ülkenin fiziki sınırlarını aşması, çifte vergileme veya çifte vergilememe olmak üzere vergilendirme yetkisinin hangi devlet tarafindan kullanılacağına ilişkin yetki sorununa neden olmaktadır. Dünyadaki bu dönüşüm vergi matrahlarında aşındırma ve kârın aktarılmasına neden olarak uluslararası vergi sistemlerinde de bir dönüşüme neden olmaktadır. Bu sorunların ülkelerin iç mevzuatlarıyla çözümlenmesi tek başına yeterli olmayacağından daha fazla uluslararası işbirliği gerekmektedir.

Ulusal vergi sistemleri arasındaki etkileşim ve bunun sonucunda ortaya çıkan uluslararası vergileme sorunlarına ilişkin çalışmalar, yirminci yüzyılın başında Milletler Cemiyeti etrafında şekillenen çabalara ve sonrasında Birleşmiş Milletler (BM) ve Ekonomik Kalkınma ve İşbirliği Teşkilatı (OECD) tarafından yapılan çalışmalara dayanmaktadır. İlk başlarda "çifte vergileme (double taxation)" sorunu üzerine inşa edilmiş olan uluslararası vergileme sorununu ele alan kurumsal yapılar 1980'li yıllardan itibaren dünyada yaşanan serbestleşme ve küreselleşme eğilimlerinin neden olduğu vergi matrahının aşındırılması ve kârın aktarılmasına ilişkin "çifte vergilememe" sorununu da gündemlerine almışlardır. Önceleri vergiden kaçınmak için sığınak haline gelen ve "vergi cenneti" olarak adlandırılan bazı ülkeler, diğer ülkelerin mali yapılarına ciddi bir tehdit oluşturmaya başlamıștır. "Panama Papers" olarak adlandırılan belgelerin gündemi meşgul etmesi konunun önemini bir kez daha ortaya koymaktadır.

OECD Model Vergi Anlaşmasının uluslarası vergilendirmede temel referans metin olarak kabul edilmesi nedeniyle çalışmamız, OECD Model Anlaşması ve Matrah Aşındırma ve Kâr Aktarımı Eylem Planı (Action Plan on Base Erosion and Profit Shifting-BEPS) bağlamında daimi işyeri ile transfer fiyatlandırması ilişkisini ortaya koyacaktır.

\section{OECD Model Vergi Anlaşmasında Daimi İşyeri}

\section{I. Daimi İşyeri Kavramı (Permanent Establishment)}

Her ne kadar ülkeler vergileme yetkisini belirlemekte ulusal yasama süreçlerinde serbest olsalar da, söz gelimi kendisinin mukimi ya da vatandaşı olmayan bir mükellefin kendi egemenlik alanında elde edilmemiş bir gelirini vergilemesi imkânsızdır. Bu nedenle vergileme yetkisinin fiilien kullanılabilir olması ülke ile gelirin yaratıldığı faaliyet, ya da geliri kazanan arasında yeterli bir mali ilişki ya da bağın bulunmasını gerektir. Bir mükellefi ya da bir vergi konusunu vergilemek hususunda meşruiyet; yerleşik, vatandaşlık, şirketin kuruluş yeri, yönetim yeri, daimi işyeri, işin icra edildiği yer ya da gelirin doğduğu yer olmak gibi bir bağlantı ya da yeterli bir ilişki ile ülkeyle ilişkilenecek meşruluk temelinin bulunması gerekir ${ }^{1}$.

1 Savaş Çevik, Küresel Ekonomide Uluslararası Vergileme, Palet Yayınları, Ekim 2013, s.12-13. 
Vergilendirme yetkisinin paylaşımında esas alınan unsurlardan biri işyeridir. İşyeri maddi bir varlıktır. Maddi bir varlık olarak vergilendirme yetkisinin paylaşılmasında işlev görmektedir ${ }^{2}$. OECD Model Vergi Anlaşması'nın 5. maddesinde yer alan işyeri terimi, elde edilen ticari kazancın hangi devlette vergilendirileceğini belirlemekte olup, Model Anlaşmanın 5. maddesinin 1. fikrası işyerine ilişkin genel bir tanım yapmaktadır. OECD Model Anlaşmasında daimi işyeri terimi, bir teşebbüsün işlerinin tamamen veya kısmen aracılığıyla yürütüldüğü işe ilişkin sabit bir yer olarak tanımlanmaktadır.

Daimi işyeri, ticari faaliyetin kaynak devletteki düzeyini gösteren bir kavramıdır. Daimi işyeri kavramı özellikle OECD Model Anlaşmasının ticari kazançlara ilişkin 7. maddesi açısından önemlidir. Ayrıca daimi işyeri, kâr paylarına ilişkin 10 uncu madde, faize ilişkin 11 inci madde gibi diğer çeşitli gelirlerle de ilgilidir. Bununla birlikte daha büyük önem 7 inci maddeye verilmiştir.

\subsection{Uluslararası Hukukta Daimi İşyeri Kavramının Kullanılmasının Amacı}

Uluslararası ilişkilerin artması sonucunda, devletlerin vergilendirme yetkilerinin sınırlarının ne olacağı da tartışılmaya başlanmıştır ${ }^{3}$. Bir ülkeden diğer bir ülkeye yapılan sınır ötesi ticaret neticesinde ortaya çıkan ${ }^{4}$ uluslararası vergilendirme doğal olarak birden fazla ülkeyi içermektedir ${ }^{5}$. Bu tür bir uluslararası ticaret neticesinde elde edilen gelir; hem özel ilişkisi nedeniyle transferin yapıldığ 1 ülkede hem de ekonomik ilişkisi nedeniyle gelirin elde edildiği ülkede birden vergilendirilebilmekte ${ }^{6}$ ve ülkeler vergileme yetkilerini, ilgili mükellef ya da vergi matrahının ülkeye olan ilgisi ile tanımlayarak vergileme yetkisini kullanmaktadırlar ${ }^{7}$.

Küreselleşmenin sonucu olarak ülkeler arasındaki siyasi sınırların kalktığı günümüzde, bir teşebbüsün bir işyeri, acente ya da şube aracılığıyla birden fazla ülkede faaliyet göstermesi mümkün olmaktadır. Ancak şirketlerin değişik biçimlerde birden fazla ülkede faaliyet göstermesi vergileme yetkisinin hangi ülke tarafından kullanılacağının belirlenmesini gerektirmektedir.

Daimi işyeri kavramının kendisi, OECD Model Anlaşmasına dayalı ikili anlaşma altında ortaya çıkabilen ticari kazaçların vergilendirilebilmesi için karşılanması gereken temel bir koşuldur. Ancak, bu tanım OECD Anlaşmasında yapılmış olsa da, bu kavram için kullanılan kavramların geniş anlamı -her bir olayın esasları ve koşulları- "daimi işyeri”nin aslında bir teşebbüs için var olduğunun tam olarak belirlenmesini vergi mükellefleri ve vergi idareleri için son derece karmaşık, zor ve tartışmalı hale getirmektedir. Bu nedenle, daimi işyeri konusu uluslararası vergilendirmenin en çekici, önemli ve karmaşık konularından biri olmaya devam etmektedir.

2 Hüseyin Işı1k, Uluslararası Vergilendirme, İstanbul: On İki Levha Yayıncılık, 2014, s.108.

3 N. Semih Öz, Uluslararası Vergi Rekabeti ve Vergi Cennetleri, Ankara: Maliye ve Hukuk Yayınları, 2005 , s.17.

4 Birol Ubay, "Elektronik Ticaretin Vergilendirilmesinde Avrupa Birliği ve OECD Yaklaşımları”, Vergi Dünyası, Sayı.381 (Mayıs 2013), s.116.

Öz, a.g.k., s.17.

Ubay, a.g.m., s.116.

Çevik, a.g.k., s.7. 
Özellikle vergi anlaşmaları çerçevesinde, mevcut sınır ötesi işlemler ve çok uluslu ticari faaliyetler kapsamındaki tanımları, sorunları ve etkilerinin araştırılması çok önemlidir ${ }^{8}$.

Bu konu ile ilgili olarak başlangıçta yapılan çalışmalarda, diğer ülkenin vergi sistemi göz önünde bulundurulmadan yalnızca bir ülkenin durumuna göre değerlendirilmeler yapılmıştır. Son zamanlarda yapılan çalışmalarda ise ülkeler arası stratejik kararları değerlendirmek için oyun teorisi kuralları kullanılmaya başlanmıştır. Bir ülkenin vergileme ile ilgili kararlarının diğer bir ülkeyi nasıl etkilediği ve karşı olarak bu ülkelerin tepkileri değerlendirilerek uluslararası yatırım hareketlerinin yönü saptanmaya başlanmıştır ${ }^{9}$. Bu nedenle uluslararası vergilemenin kuralları temelde, bir iktisadi işlemin tarafı olmuş kaynak ve ikamet ülkeleri arasındaki ulusal vergileme yetkisindeki karmaşıklığı çözmek amacına yönelik olarak oluşmuştur. Bu işlev, sınır-aşan vergi matrahını ülkelerle ilişkilendiren, ikamet ilkesi ${ }^{10}$, kaynak ilkesi ${ }^{11}$, daimi işyeri vb. gibi bir dizi yasal yapı ile yerine getirilir. Böylece kurallar, vergileme yetkisini belirlemek için, verginin mükellefi ya da matrahı ile ilgili vergileme otoritesi arasında bağ kurmaya yöneliktirler ${ }^{12}$.

İşyeri kavramının uluslararası vergi hukukunda kullanılmasının başlıca amacı, bir devletin ülkesinde faaliyet gösteren herhangi yabancı bir teşebbüsün kazancının o devlet tarafından vergilendirilebilmesine ilişkin hakkının belirlenmesidir ${ }^{13}$. Ticari faaliyetlerin vergilendirilmesinde vergilendirme yetkisi, tamamen olmasa da genel olarak, ikamet ülkeye bırakılmaktadır. Vergilendirme yetkisinin kaynak ülke tarafından kullanılabilmesinin uluslararası vergilemede ölçütü, bir ülkede daimi işyeri aracılığıyla faaliyette bulunup bulunulmadığıdır. Ticari faaliyetlerin vergilendirilmesinde kaynak ve ikamet ülkeleri arasında vergilendirme yetkisinin paylaştırılması açısından daimi işyeri önemlidir. İşyeri kavramının önemi, bu kavramın Model Vergi Anlaşmalarında düzenlenmesine neden olmuştur. OECD Model Anlaşmanın tarafı olan bir Devletin mukimi tarafından kaynak Devlette elde edilen ticari kazançların hangi eşik değerlerde kaynak Devlette vergilendirilebileceği 5 inci maddede tanımlanır.

8 Leonardo F. M. Castro, “Problems Involving Permanent Establishments: Overview of Relevant Issues in Today's International Economy”, http://www.globalbusinesslawreview.org/wp-content/uploads/2012/04/1gCastro.pdf, (Erişim: 20.04.2016), s. 129.

9 Öz, a.g.k., s.17.

10 İkamet İlkesi: İkamet ilkesine göre, kişi gerek bulunduğu (yani ikamet ettiği) ülkede gerekse bu ülke dışından elde ettiği gelirin toplamı üzerinden vergilendirilir. Bu durumda, vergilendirme yetkisini kullanan devlet ile ülkesel bağ içinde olan vergi konusu değil vergi yükümlüsüdür. Bu durumun meşruluğu, vergi yükümlüsünün, o devletin mukimi olması dolayısıyla "kişisel anlamda ülkesel egemenlik" altında olmasında yatmaktadır.

Selâhattin Tuncer, Çifte Vergileme ve Milletlerarası Vergi Anlaşmaları, Ankara: Sevinç Matbaası, 1974, s.16. ve Billur Yaltı Soydan, Uluslararası Vergi Anlaşmaları, İstanbul: Beta Basım, 1995, s.19.

11 Kaynak İlkesi: Devletin, “ülkesel egemenliği” altında bulunan vergi konuları ve vergi doğurucu olayları vergilendirmesidir. Bu ilkede vergilendirmeye temel olan husus, gelirin doğduğu yerdir. Kaynak ilkesi, bir devletin vergi yasalarını ülkesinde bulunan yerli ya da yabancı herkese ve bütün hukuksal işlemlere uygulaması anlamına gelir ve kaynağını "kişisel olmayan anlamda ülkesel egemenlikten (territoriality in the real sense)" alır. Buradaki hukuksal ilişki "ekonomik bağ” temeline dayanmakta ve vergi yükümlüsünün ikametgâhının yeri veya uyrukluğunun bir önemi bulunmamaktadır.

Yaltı Soydan, a.g.k., s.17-18.

12 Çevik, a.g.k., s.12.

13 Cihat Öner, Vergi Hukukunda İșyeri, Ankara: İmaj Yayınevi, 2016, s.3-4. 


\subsection{OECD Model Anlaşmasında Daimi İşyeri ve Ticari Kazanç Arasındaki İlişki}

Çifte vergilendirmeyi önlemeye ilişkin vergi anlaşmaları (“çifte vergilendirme anlaşmaları" ya da sadece "vergi anlaşmaları" olarak da bilinen), kendi mülki sınırları içinde bir kişi ya da bir işletmenin vergilendirilmesinde asgari bağ kurmak için ikamet kriterini kullanmaktadır. Bir Devletin yetki alanı sınırları içindeki etkin bir yönetim yeri ya da genel merkezin varlı̆̆ı genellikle bir Devlet ile bu özel konu arasındaki egemenlik ilişkisinin doğasında olan ekonomik ve sosyal önemi ortaya koyan yeterli bir faktör olarak kabul edilir. Bu nedenle, Devlet içinde oluşan gelir doğrudan bu Devlet içinde kurulan teşebbüse atfedilebilir ve dolayısıyla kazançları vergilendirmeye konu edilebilir ${ }^{14}$.

Bir Akit Devlet teşebbüsünün diğer Akit Devlette elde ettiği kârlar diğer devletteki işyerine atfedilmediği sürece diğer devlette vergilendirilmeyecektir. Diğer devlette vergilendirme için burada kâr elde edilmesi ve kârın bu devletteki bir işyeri aracılığıla elde edilmesi gerekmektedir. Teşebbüs bir bütün olarak kâr elde etmemiş olsa dahi, diğer devletteki işyeri vasıtasıyla kâr edilmesi halinde, bu kârın işyerine atfedilmesi gerekmektedir ${ }^{15}$.

Daimi işyeri kuralına bakıldığında, OECD Model Anlaşmasının 7 inci maddesiyle (Ticari Kazançlar) aynı zamanda getirildiği görülmektedir. Madde 7 nin şerhi çifte vergilendirme anlaşmalarının genel kabul görmüş ilkelerini belirtmektedir: Bir Akit Devlet teşebbüsünün kazancı, teşebbüs diğer Akit Devlette bulunan daimi işyeri aracılığıyla ticari faaliyetini devam ettirmedikçe sadece bu Devlette vergilendirilebilir ${ }^{16}$.

İşyeri kavramı ticari kazançların kaynak devlette vergilendirilebilmesinin en temel koşullarından biri olarak görülmektedir. Hatta bunun asgari koşulu olduğu da söylenebilir. Dolayısıyla, kavramın sabit bir yerden yürütülen faaliyetler ile ilgili olma koşulundan çok daha karmaşık bir takım alanlara temas ettiği görülmektedir. Sabit yer koşulu bir dar mükellefin bir devlette fiziksel olarak bulunmasına ilişkin kuralın doğasını, özünü yansıtmaktadır. Bununla birlikte dar mükelleflerin bir devlette sadece fiziksel olarak bulunuyor olmaları ya da sadece iş yürütüyor olmaları vergilendirilebilmeleri için yeterli değildir; belli bir takım sabit yerlerin, örneğin ofis, büro gibi, belli bir süre boyunca kullanım hakkına sahip olmaları da aranmalıdır. Anılan gerekliliğin bu yönü sabit yerde yürütülen işlerin mahiyeti ile ilgili olarak bazı değişikliklere uğramıştır. Bu nedenle yürütülen faaliyetlerin hazırlayıcı ve yardımcı olmanın ötesine geçmesi gereklidir $^{17}$.

Mükellef işyerine atfedilecek gelirler nedeniyle işyerinin bulunduğu devletin vergilendirmesine tabi tutulacaktır. $\mathrm{Bu}$ nedenle işyerinin tanımının geniş tutulması halinde bulunduğu devletin vergilendirme olanağı artacaktır. Aksi durumda yani işyeri tanımının dar tutulması halinde

Castro, a.g.m., s.128.

Işık, a.g.k., s.134.

Castro, a.g.m., s. 143-144.

Öner, a.g.k., s.20. 
ise, bulunduğu devletin vergilendirme olanağ ${ }^{\prime}$ azalacaktır ${ }^{18}$. Vergi anlaşmalarının 7 . maddesi uyarınca, akit devletler kendi ülkelerinde bir işyeri aracılığıyla faaliyette bulunmayan bir işletmenin kazancını vergilendiremezler. Kazancın niteliği belirlendikten sonra bunun vergilendirilip vergilendirilmeyeceğine işyerinin varlığına bağlı olarak karar verilecektir. Bu nedenle işyerinin vergi anlaşmaları bakımından maddi bağlama noktasını teşkil ettiği söylenebilir ${ }^{19}$. Böylece ticari kazancın vergilendirilmesi ile ilgili olarak OECD Model Anlaşmasına göre, bir ülkede gerçekleştirilen faaliyetler daimi işyeri ölçütünü karşılarsa bu faaliyetlerden elde edilen gelir kaynak ülke tarafından vergilendirilecek, aksi takdirde vergilendirme yetkisi ikamet ülkesine ait olacaktır ${ }^{20}$.

Bu açıdan başka bir ülkenin yerleşiği bir şirketin kaynak ülkesindeki faaliyetlerinin bir daimi işyeri olarak kabul edilip edilmeyeceği, yani daimi işyerinin nasıl tanımlandığı görece vergileme yetkisi paylaşımlarını değiştirecektir. Her ne kadar model anlaşmalarda bir çerçeve bulunabilirse de fiili anlaşmaların kullandıkları tanımlar birbirinden oldukça farklı olabilir. Bu çeşitlilik taraf ikamet ve kaynak ülkelerinin birbirleri karşısında sahip oldukları pazarlık gücünden kaynaklanabilir. Zira ikamet ülkesinin daimi işyeri kavramının daha sınırlı kapsamda kullanılması, aksine kaynak ülkesinin kapsamına girecek faaliyetleri artırmak için daha geniş bir tanımlamadan taraf olması beklenir ${ }^{21}$. İkamet ülkesinde yerleşik bir teşebbüsün kaynak ülkede bir daimi işyeri aracılığıyla faaliyette bulunması halinde kaynak ülke yalnızca bu daimi işyerine atfedilebilen gelirleri vergileme yetkisine sahip olacaktır. Başka bir ifadeyle, kaynak ülkesi vergilendirme yetkisini, bu ülkedeki daimi işyeri aracılığıyla elde edilen gelirle ilişkili olarak kullanabilecektir.

\subsubsection{OECD Model Anlaşmasında İşyeri ve Serbest Meslek Kazançları Arasındaki İlişki}

OECD Model Vergi Anlaşmasının 14. maddesiyle ilgili sorunlar başlıklı rapora dayanarak "Bağımsız Kişisel Hizmetler" başlıklı 14 üncü madde 29 Nisan 2000 tarihinde Model Vergi Anlaşmasından çıkarılmıştır. Bu karar aslında 7 inci maddede kullanıldığı haliyle daimi işyeri kavramı ile 14 üncü maddede kullanıldığı haliyle sabit yer arasında ve 7 ya da 14 üncü maddenin uygulamasında kazancın nasıl hesaplandığ 1 veya verginin nasıl hesaplandığ bir farklılık bulunmadığ 1 gerçeğini yansıtmaktadır. Ancak, 7 inci maddenin aksine 14. maddenin içinde yer alan faaliyetler her zaman açık değildi. Serbest meslek kazançları ya da bağımsız nitelikteki diğer faaliyetlerden elde edilen bu gelire ilişkin 14 üncü maddenin çıkarılması bu gelirlerin ticari kazanç olarak 7 inci maddede ele alınmasına neden olmuştur ${ }^{22}$. Başka bir deyişle, “Ticari Kazançlar”a ilişkin yorum ve açıllamalar serbest meslek faaliyetlerine ilişkin yorum ve uygulamalarda da kullanılabilecektir. Ticari kârın ana merkez ile işyeri arasında dağıtımına ilişkin

Işık, a.g.k., s.109.

Öner, a.g.k., s.3-4.

20 OECD, "Model Convention With Respect to Taxes on Income and on Capital", 2014, https://www.oecd.org/ctp/ treaties/2014-model-tax-convention-articles.pdf, (Erişim: 15.03.2016), s.28.

21 Çevik, a.g.k., s.66.

22 OECD Committee on Fiscal Affairs, "Model Tax Convention on Income and on Capital", 22 July 2010, webdms. ciat.org/action.php?kt_path_info=ktcore.actions...view..., (Erişim: 20.04.2016), s.656. 
ilkeler, serbest meslek kazancı ile ilgili mesleği icra edenin mukimi olduğu devlet ile faaliyetin sabit yer vasıtasıyla icra edildiği diğer devlet arasında dağıtımında kullanılabilecektir. Benzer şekilde işyerinin amaçlarına uygun olarak ticari kazançtan indirilmesine izin verilen yönetim ve genel idare giderlerinde olduğu gibi sabit yerin amaçlarına uygun olan benzer nitelikte ve aynı esaslara göre hesaplanan giderlerin indirilmesine izin verilecektir ${ }^{23}$. Dolayısıyla serbest meslek faaliyetleri kapsamında bulunan ekonomik faaliyetlerden elde edilen gelirler Model Anlaşmanın 7 inci maddesinde düzenlenen ticari kazançlara ilişkin madde kapsamında vergiye tabi tutulacaktır. read on 22 July

Ancak “Ticari Kazançlar” ve "Serbest Meslek Faaliyetleri” konusundaki düzenlemelerin aynı ilkelere dayanması, her ikisinin de aynı şekilde açıklanacağı ve uygulanacağı anlamına gelmemektedir. İşyeri kavramının ticari ve sınai faaliyetlerin icrasında kullanılan yer olması karşısında, sabit yerin de bu faaliyetler için kullanılacağı sonucuna ulaşılamayacaktır. Sabit yer kavramını ticari ve sınai faaliyetlerle bağlantılı olarak tanımlamak doğru bir yol gibi gözükmemektedir. Böyle bir tanımlama yerine fizik tedavi uzmanının muayenehanesi, avukat veya mimarın bürosu sabit yer tanımına uygun düşmektedir. Serbest meslek faaliyetini icra eden bir kişi için mukimi olduğu devlette faaliyetin icrası için sabit bir yerin varlığı gerekli olmayabilecektir. Buna karşılık diğer devlet kendi ülkesinde serbest meslek faaliyetinin icrası için sabit yerin bulunduğu veya daimi kalıcılı̆̆ın bulunduğu durumlarda, serbest meslek erbabını vergilendirme yoluna gidebilecektir ${ }^{24}$.

\section{3. Çok Uluslu Şirketler ile Daimi İşyeri Arasındaki ilişki}

Uluslararası vergi hukukunda işyeri ile ilgili olarak, çok uluslu grup şirketler bünyesinde yer alan ve birbirleri ile ilişkili olan yavru şirketlere nasıl yaklaşılacağı konusu uygulamada karşılaşılan önemli sorunlardan birisidir. Bu tür şirket yapılanmalarında her bir şirket, grup şirketin bir bütün olarak güttüğü ticari amaçlara katkı sağlamak ile yükümlüdür. Kavramsal ve ticari bakımdan konu ele alındığında, grup şirketin faaliyetlerinin bir bütün olarak veya diğer bir ifade ile entegre bir faaliyet olarak ele alınması gerekli sayılabilir. Bununla birlikte OECD Modelinin 5. maddesinin amaçlarının gerçekleştirilmesi bakımından, çok uluslu grup şirketler içinde yer alan her bir şirketin ayrı ayrı ele alınması şarttır. Dolayısıyla vergi anlaşmalarında yer alan her şirketi ayrı ele almaya yönelik ilke ile grup şirketleri ticari anlamda bir bütün olarak kabul etme konusundaki yaklaşım zaman zaman birbiri ile çatışabilir. Özellikle 5. maddenin uygulanması bakımından grup içinde yer alan bir şirketin diğer şirketler bakımından hatta bazen grubun tamamı bakımından bir işyeri olarak değerlendirilip değerlendirilmeyeceği tartışma konusu olmuştur. Bu sorunun çözümü oldukça güçtür ${ }^{25}$.

Işık, a.g.k., s.232.

Işık, a.g.k., s.232.

Öner, a.g.k., s.172-173. 


\section{OECD Model Vergi Anlaşmasında Transfer Fiyatlandırması}

Ticari kazançlar ile ilgili düzenlemeler işyeri kavramının devamı ve ona bağlı nitelik taşımaktadır. Ticari kazanç elde edilmesi işyeri marifetiyle olmaktadır. Vergi anlaşmalarında ilk önce işyeri teriminin tanımı yapılmaktadır. İşyeri tanımı yapıldıktan sonra işyerine atfedilecek kârlar ile ilgili düzenlemeler ticari kazanç bahsinde belirlenmektedir. Ticari kazancın belirlenmesi ile ilgili diğer bir düzenleme ise Bağımlı Teşebbüsler başlıklı 9 uncu maddedir. Bağımlı teşebbüslerle ilgili düzenlemeler, teşebbüsler arasında bağımlılık ilişkisi bulunduğu durmlarda bunlar arasındaki işlemlerden kaynaklanan kârın nasıl dağıtılacağını belirlemektedir. Ticari kazancın, iki ayrı devlette yer alan, ancak birbirleriyle bağımlı iş yerleri vasıtasıyla elde edilmesi halinde kâr, ikisi arasında katkıları ölçüsünde bölüştürülmektedir ${ }^{26}$.

OECD Model Anlaşmasının 7 inci maddesinin 2 inci fikrasında bir Akit Devlet teşebbüsünün diğer bir Akit Devlette yer alan bir daimi işyeri aracılı̆̆ıla ticari faaliyette bulunması durumunda, her bir Akit Devletteki daimi işyerine atfedilebilecek kârlar, özellikle daimi işyeri ve teşebbüsün diğer bölümleri aracılığıyla teşebbüs tarafından üstlenilen riskler ve kullanılan varlıklar, gerçekleştirilen işlevler dikkate alınarak aynı veya benzer koşullar altında aynı veya benzer faaliyetlerde bulunan ayrı ve bağımsız bir teşebbüs olsaydı elde etmeyi beklediği kâr ile aynı miktarda olacaktır ${ }^{27}$.

Maddenin 2 inci fıkrası diğer devlette bulunan işyerine atfedilecek kârın tespitinin, bu işyerinin teşebbüsten ayrı ve bağımsız bir varlık gibi değerlendirilmesini ve teşebbüsle yaptığı işlemlerin emsallere uygun olması gerektiğini ortaya koymaktadır. Bunlar arasında ticarin kazancın bölüştürülmesi ayrı varlık yaklaşımı ve emsallere uygunluk ilkeleri çerçevesinde yapılacaktır ${ }^{28}$.

\section{I. Fonksiyonel Ayrı Varlık Yaklaşımı (Functionally Separate Entity Approach)}

Bağımlı teşebbüsler arasında gerçekleşen işlemlerin karmaşık olması kârın nasıl dağıtılacağı sorusunu gündeme getirmektedir. Bu konuya OECD Model Anlaşmasında yer verilmiştir. Ancak, bağımlı teşebbüsler arasında gerçekleşen işlemlerin karmaşık olması kârın nasıl dağıtılacağı sorusuna verilecek cevabın kesin olmasını engelleyebilmektedir. Bu durum ise çifte vergilendirme veya çifte vergilendirmemeye neden olabilmektedir.

OECD’nin 2008 yılında yayımladığı Daimi İşyeri ile Gelirin İlişkilendirilmesi Raporu (Report on the Attribution of Income to Permanent Establishments) ${ }^{29}$, daimi işyerinin çeşitli amaçlarla kendisinin yurtdışındaki ana şirketinden ayrı bir varlık olarak kabul edildiği durumlarda işlevsel ayrı varlık (functionally separate entity) yaklaşımını benimser. Bu

Işıı, a.g.k., s.131.

OECD, "Model Convention With Respect to Taxes on Income and on Capital", s.28.

Işık, a.g.k., s.131.

29 OECD, "Report on the Attribution of the Profits to Permanent Establishment", 2008, http://www.oecd.org/tax/ transfer-pricing/41031455.pdf, (06.07.2016). 
yaklaşıma göre, "daimi işyerine atfedilen kârlar madde 7(2) kapsamında emsallere uygunluk ilkesinin uygulanmasıyla belirlenen aynı ya da benzer koşullarda aynı ya da benzer işlevleri yerine getiren "farklı ve ayrı" teşebbüsün elde ettiği gibi emsallere uygun elde edilen kârlardır. Bu nedenle, OECD’nin “Çok Uluslu Şirketler ve Vergi İdareleri için Transfer Fiyatlandırması Rehberi” transfer fiyatlandırması kurallarına göre daimi işyerine atfedilebilir kârları belirlemek için bir kılavuz olarak kullanılacaktır. Bu açıdan, OECD Model Anlaşma şerhi bir daimi işyerine atfedilecek kârların daimi işyerinin gerçekleştirdiği işlevler, üstlenilen riskler ve kullanılan varlıklarla ilişkili olarak belirlenmesi gerektiğini öngörmektedir. Bu işlevsel ayrı varlık yaklaşımı, bağımlı acenta daimi işyeri olsa bile geçerlidir. Bağımlı acentanın kendisi bir tüzel kişi ve bir vergi mükellefi ise kârın genel transfer fiyatlandırması ilkeleri altında bağımlı acentaya atfedilmesinden sonra sorun, daimi işyerine atfedilen herhangi bir kâr olup olmayacağı konusunda ortaya çıkmaktadır. Bu durumlarda daimi işyerine gelirin nasıl tahsis edileceğine ilişkin belirleyici faktör riskin üstlenilmesiyle ilgilidir. Daimi işyeri bağlamı dışında, transfer fiyatlandırması kuralları, bir vergi mükellefinin aldığı risklerle orantılı olarak gelir elde etmesi gerektiğini belirtmektedir ${ }^{30}$.

Konu ile ilgili olayların çoğunluğunda farklı şubeler ve işyerlerine atfedilebilecek kârların tespitine olanak sağlayacak şekilde ayrı muhasebe hesapları tutulmaktadır. Özellikle şubelerdeki kârlılıkları görmek isteyen teşebbüsler bunu sağlayabilecek şekilde ayrı muhasebe sistemleri kurmaktadır. İstisnai durumlarda ise ayrı muhasebe olmayabilmektedir. Ayrı hesapların bulunduğu durumlarda işyerine atfedilen kârın dağıtımının doğruluğunun tespitinde var olan bilgilerden hareketle işe başlanması yerinde olacaktır. Varsayımlardan hareket etmek yerine var olan kayıtlardan hareket etmek ve bu kayıtlardaki verilerin ayrı varlık yaklaşımına ve emsallere uygunluk ilkesine uygun olup olmadığını irdelemek gerekecektir. Birinci adım olarak işyerinin yürüttüğü faaliyetlere bakılacaktır. Yürütülen faaliyetlerin incelenmesi işlerin ve verilerin analizleri ile yapılacaktır. İlk olarak işyerinin yürüttügüu ekonomik olarak önemli faaliyetler ile üstlendiği riskler tanımlanacaktır. İşyerinin yürüttüğü faaliyetler ve üstlendiği riskler, teşebbüsün bir bütün olarak yürüttügü faaliyet ve üstlendiği riskler dikkate alınarak daha geniş bir perspektifte ele alınması makul olacaktır. Bu yapılırken teşebbüs ile işyeri arasında yürütülen işlemlere özellikle dikkat edilmesi yerinde olacaktır. İkinci adımda ise teşebbüs ile işyeri arasındaki işlemlerin sayısal olarak ifade edilmesi diğer bir deyişle sayısallaştırılması emsallere uygunluk ilkesine göre yapılacaktır. Teşebbüs ile işyeri arasında işlemlerin emsallerine uygun olarak, ifade edilmesi; ifa edilen işlevler, kullanılan varlıklar ve üstlenilen risklerin teşebbüs ile işyeri arasındaki ilişkiye tekabül eden kısmı ile teşebbüsün diğer kısımlarına düşen miktarları esas alınarak yapılacaktır. Bu yapıldıktan sonra teşebbüs ile işyeri arasındaki ilişki sayışallaştırılarak her birine düşen kârlar hesaplanacaktır ${ }^{31}$.

30 Castro, a.g.m., s.145.

31 Işık, a.g.k., s.135-136. 


\section{BEPS Kapsamında Yapılan Çalışmalarda Daimi İşyeri Kavramı ve Emsallere Uygunluk İlkesi İlişkisi}

\section{I. Daimi İşyeri Kavramına İlişkin Yapılan Çalışmalar}

Uluslararası işlem ve ticaretin artması ve teknolojik ve finansal yeniliklerle hacmi ulusal ekonomileri tehdit edecek boyuta ulaşan vergi dolandırıcılığı (tax fraud), vergi kaçırma (tax evasion) ve mükelleflerin kanunların niyet ettiğinin ötesinde boşluklardan ve ülkeler arasındaki farklılıklardan yararlanarak yaptıkları vergi planlamaları ülkelerin gelir yaratma, ekonomi politikaları uygulama ve mali yeniden yapılanma programlarını yürütme kabiliyetlerini kısıtlar. Çoğu ülkenin içinde bulunduğu mali denge, disiplin ve kamu borç sorunları dikkate alındığında yaşanan gelir kayıpları ve matrah erozyonları devletler için oldukça önemli sorunlardır ${ }^{32}$. Teknoloji ve haberleşmeye ilişkin gelişmeler, dijital ürünlerin internet üzerinden tesliminin artışıyla elektronik ticaretin artması ve en önemlisi daimi işyeri oluşumunun vergi planlamaları ile suiistimal edilmesinin yaygınlaşması karşısında daimi işyeri kavramı uluslararası vergi hukukunda yeniden değerlendirilmesi gereken bir olgu haline gelmiştir.

Mükellefler küresel ekonominin, ülkeler arasındaki mevzuat farklılıklarının ve vergi anlaşmalarının verdiği olanaklardan yararlanarak, işlemin türünü değiştirmek, işlemin ülkesini değiştirmek gibi yollarla küresel vergi yüklerini azaltmaya girişebilirler. Uluslararası ticaretin hacmi dikkate alınırsa bu gibi işlemler dolayısıyla ülkelerin vergi geliri kayıplarının önemli miktarlara ulaşması beklenebilir. Bu yüzdendir ki ülkeler gerek dâhili vergi mevzuatları (kaçınma karşıtı düzenlemeler) ile gerekse de vergi anlaşmaları aracılığıyla kontrol dışı ve "saldırgan" (aggressive) vergiden kaçınma ve vergi planlaması ile mücadele etmeye girişirler ${ }^{33}$. Günümüzde yabancı bir devlette faaliyette bulunan girişimciler işletmelerini işyeri oluşturmayacak şekilde tasarlama gayreti içindedirler. Böylelikle OECD Modelinin 5/(5) maddesi hükümlerinden kaçınmış olurlar ${ }^{34}$.

Uluslararası düzeyde vergi planlaması, vergi yükünü azaltmak üzere ulusal vergi kurallarını karşılaştırmak suretiyle farklı vergileme yetki alanlarının kullanılması ile ilgilidir. Çok uluslu şirketlerde olduğu gibi mükellefin çok sayıda vergileme yetki alanında iktisadi faaliyetleri varsa ülkeler arasındaki vergi sistemlerindeki farklılıklardan istifade ederek vergi yükünü minimize etmeye çalışmak çok daha kolay olacaktır ${ }^{35}$. Ülkelerin vergi sistemleri arasındaki farklılıklar basitçe kaynak ve ikamet ülkesi olmak açısından olabileceği gibi, ikameti ve mükellefiyeti tanımlamakta farklılıklardan gelirin niteliğini ya da kaynağını tanımlamakla ilgili farklılıklara kadar genişleyebilir ${ }^{36}$.

\footnotetext{
Çevik, a.g.k., s.143-144.

Çevik, a.g.k., s.145.

Öner, a.g.k., s.24-25.

Yazarın notu: Ülkelerin vergi sistemlerindeki farklılıkların avantajlarından yararlanmak biçiminde vergi planlamaları genel olarak 'uluslararası vergi arbitrajı' olarak ifade edilmektedir.

Çevik, a.g.k., s.145-146.
}

36 
Kaynak devlette vergilendirme konusunda asgari koşulların öngörülmesinde gözlenen çekimserliğin iki temel nedeni vardır. Bunlardan ilki vergi gelirleri, ikincisi ise vergiden kaçınmadır ${ }^{37}$. 2012 yılındaki Meksika toplantısının sonuç bildirgesinde matrah aşındırma ve kârın aktarılmasının önlenmesi ihtiyacı belirtilmiştir ${ }^{38}$. Çifte vergilendirmeyi etkin bir biçimde önlemek ve yapay uygulamalar ile vergiden kaçınılmasını önlemek amacıyla G20 ülkelerinin talebi üzerine OECD tarafından, Matrah Aşındırma ve Kâr Aktarımı Eylem Planı (Action Plan on Base Erosion and Profit Shifting-BEPS) 19 Temmuz 2013 tarihinde açıklanmıştır.

Bu eylem planı mevcut mekanizmada temel değişiklikler öngörmekte ve anlaşma hükümlerin kötüye kullanımınıönleyici görüş birliğitemelliyeni bir yaklaşımın benimsenmesini gerektirmekte olup, matrah aşındırma ve kâr aktarımını önlemek ve mücadele etmek için tasarlanmıştır ${ }^{39}$. Uluslararası vergi kaçırma ile mücadele ve vergileme konusunda işbirliği ve şeffaflık, Washington, Londra, Pittsburgh, Toronto, Seul ve Cannes'te düzenlenen G-20 zirvelerinin ana gündemleri olmuştur. G-20 çerçevesinde yapılan çalışmalar; vergi matrahının erozyonuna ve zararlı vergi rekabetine karşı mücadelenin iki genel kabul görmüş politik öncelik olduğunu göstermektedir ${ }^{40}$. Temmuz 2013'de yayımlanan OECD’nin Matrah Aşındırma ve Kâr Aktarımı Eylem Planı, BEPS’e ilişkin 15 eylemi kapsamlı bir şekilde tanımlamakta ve bu eylemleri uygulamak için tarihler belirlemektedir ${ }^{41}$.

BEPS raporu, BEPS'in esas nedenlerini tanımlamakta ve BEPS’e yola açan vergi planlamasının koordine edilmiş taktik bileşimlerine dikkat çekmektedir. BEPS Raporundaki aşağıdaki paragraf daimi işyerinin mevcut anlaşmadaki tanımına ilişkindir ${ }^{42}$ : Daimi işyeri kavramının ilgili ülkede sadece fiziksel varlığı ifade etmediği, aynı zamanda ilgili ülkede mukim olmayan bir bağımlı temsilci (Dolayısıyla kurallar OECD Modelinin 5 inci maddesinin 5 ve 6 inci paragraflarında yer almaktadır.) aracılığıyla da işlerin sürdürüldüğü geçmişte kabul edilmişti. Günümüzde bir teşebbüsün bir başka ülkenin ekonomik hayatında ağırlıklı olarak bulunulması mümkündür, örneğin vergiye tabi bir varlığı (fiziksel varlığı ya da bağımlı temsilci gibi) bulunmadan o ülkede yerleşik müşterilerle iş yapılması. Dar mükelleflerin diğer ülkede yerleşik müşterilerle gerçekleştirdikleri işlemlerden önemli kârlar elde ettiği bir dönemde, özellikle de bu işlemlerden elde edilen kârın vergilendirilmemiş yerlere gittiği durumlarda mevcut kuralların ticari kazançlar üzerindeki vergilendirme yetkisinde adil bir paylaşım sağlayıp sağlamadığı sorusu gündeme gelmektedir.

37 Öner, a.g.k., s.24.

38 G20 Leaders Declaration, G2012, Mexico, http://www.consilium.europa.eu/uedocs/cms_Data/docs/pressdata/en/ ec/131069.pdf, (16.08.2016).

39 OECD, "Action Plan on Base Erosion and Profit Shifting", 2013, s.13. https://www.oecd.org/ctp/BEPSActionPlan. pdf, (Erişim: 10.02.2016).

40 Çevik, a.g.k., s.143-144.

41 OECD, "BEPS Action 7: Preventing The Artificial Avoidance of PE Status", Revised Discussion Draft, 15 May $2015-$ 12 June 2015, http://www.oecd.org/tax/treaties/revised-discussion-draft-beps-action-7-pe-status.pdf, (Erișim: 28.04.2016), s.1.

42 OECD, "BEPS Action 7: Preventing The Artificial Avoidance of PE Status", Public Discussion Draft, 31 October 2014-9 January 2015, https://www.oecd.org/ctp/treaties/action-7-pe-status-public-discussion-draft.pdf, (Erişim: 18.04.2016), s.9. 
BEPS raporu, komisyoncu düzenlemelerinin kullanımı ve spesifik faaliyet istisnaları da dahil olmak üzere matrah aşındırma ve kâr aktarımına ilişkin yapay daimi işyeri oluşumundan kaçınmayı önlemek için daimi işyeri tanımında değişiklikler geliştirmeyi ve kârla ilişkili sorunları ele alan bu konularda çalışmayı amaçlamaktadır ${ }^{43}$.

5 Ekim 2015 tarihinde, G20 Maliye Bakanlarının 8 Ekim'deki Lima toplantısı öncesinde, OECD Matrah Aşındırma ve Kâr Aktarımı (BEPS) Projesine ilişkin Eylemler üzerinde uzlaşmaya varılan görüşleri özetleyen 13 bildiri ve bir açıklayıcı bildirim yayınladı. Bu bildiriler 2014 yılında Brisbane Zirvesi'nde G20 Liderleri tarafından sunulan ve memnuniyetle karşılanan ilk yedi raporu kapsamakta ve birleştirmektedir. BEPS Eylemlerinin herbirinin altındaki çıktılar, uluslararası vergi çevresinde model vergi anlaşması ve transfer fiyatlandırması kuralları uyarınca iç hukuk önerileri ve uluslararası ilkeleri içeren kapsamlı ve tutarlı bir yaklaşım oluşturmak için tasarlanmıştır. Onlar büyük ölçüde "asgari standart”, "en iyi uygulama” veya hükümetlerin benimsemesi için “öneriler” olarak sınıflandırılır. 2015 çıktısının bir parçası olarak, OECD Sekreterliği model anlaşmada değişiklikler getiren yapay daimi işyeri oluşumundan (Eylem 7) kaçınmanın önlenmesi ile ilgili bir taslak yayınladı. Rapor, G20/OECD’nin Ekim 2014 ve Mayıs 2015'deki tartışma taslaklarında ileri sürülen önerilere dayanmakta ve OECD’nin vergi anlaşması modelinin 5 inci madddesi ve ilgili şerhlerindeki daimi işyeri tanımını (vergiye tabi varlık) güncellemektedir. Taslak, bir yurtdışı ülkede bulunan bir şirketin ticari kazançlarının vergilendirilebilmesi için oluşması gereken daimi işyerinin mevcut eşiklerinde geniş kapsamlı değişiklikler yapmaktadır.

Ayrıca taslak, mukim olmayan bir işletme tarafından gerçekleştirilen düzenli sözleşmelerin sonucunda bir ülkede bir "aracı" tarafından gerçekleştirilen faaliyetlere ilişkin durumları ve aracı kendi işlerinin normal seyri içinde hareket eden bağımsız bir acenta olmadıkça mukim olmayan işletmenin bu ülkede vergiye tabi işyerine sahip olduğunu belirtilmektedir. Sonuç olarak, rapor komisyoncu ve diğer açıklanmayan acenta düzenlemelerini ele almayı amaçlayan bağımlı ve bağımsız acenta kurallarına ilişkin değişiklikleri içermektedir ${ }^{44}$.

\subsection{Transfer Fiyatlandırmasına İlişkin Yapılan Çalışmalar}

2013 yılında OECD ve G20 ülkeleri tarafından benimsenen Matrah Aşındırma ve Kâr Aktarımı Eylem Planı(BEPS) yüksek düzeydeki transfer fiyatlandırması ve riskle ilgili diğer BEPS konularını değerlendirmek için vergi idarelerine yeterli bilgi sunarak onlar için şeffaflı̆̆ın arttırılmasının BEPS sorununun çözümünde önemli olduğunu kabul etmektedir ${ }^{45}$.

43 OECD, "Action Plan on Base Erosion and Profit Shifting", s.19.

44 Deloitte, "BEPS Action 7: Preventing the Artificial Avoidance of Permanent Establishment Status", Ireland, http:// www2.deloitte.com/content/dam/Deloitte/ie/Documents/Tax/BEPS\%20Action\%207\%20-\%20Artificial\%20 avoidance\%20of\%20permanent\%20establishment\%20status\%20-\%20October\%202015.pdf, (Erişim: 20.04.2016), s.1-2.

45 OECD, "OECD/G20 Base Erosion and Profit Shifting Project-Action 13: Country-by Country Reporting Implementation Package", 2015, http://www.oecd.org/tax/transfer-pricing/beps-action-13-country-by-countryreporting-implementation-package.pdf, (Erişim 29.04.2016), s.5. 
$\mathrm{Bu}$ nedenle transfer fiyatlandırması ve emsallere uygunluk ilkesinin uygulanması önemli bir konudur. Transfer fiyatlandırması kuralları çok uluslu şirketlerin iş yaptıkları ülkeler arasında kazanılan gelirin bölüştürülmesine çalışmaktadır. Birçok durumda, emsallere uygunluk ilkesine dayalı mevcut transfer fiyatlandırması kuralları, çok uluslu gelirleri vergilendirme yetkisi alanları arasında etkin ve verimli olarak bölüştürmektedir. Diğer durumlarda ise, çok uluslu şirketler bu kuralları kullanarak ve/veya yanlış uygulayarak ekonomik faaliyetlerden elde edilen geliri ayırabilmekte ve düşük vergi ortamlarına kaydırabilmektedir. Bu genellikle gayrimaddi varlıkların ve diğer hareketli varlıkların tam değerinin altındaki tutarlardan naklinden, düşük oranda vergilendirilen aşırı değerlenmiş grup şirketlerin ve ilişkisiz taraflar arasında gerçekleşmesi ihtimali olmayan düşük vergi ortamları için sözleşme tahsis biçimleri riskinden kaynaklanabilir ${ }^{46}$.

Transfer fiyatlandırması ile ilgili olarak yapılan çalışmalarda formül tabanlı sistemler de dahil olmak üzere alternatif gelir dağıtım sistemleri önerilmektedir. Ancak tüm ülkelerde yeni bir sistemin üzerinde anlaşılması ve uygulamasının pratik zorlukları karşısında, mevcut transfer fiyatlandırması sisteminin değiştirilmesi yerine en iyi yol özellikle gayri maddi duran varlıklar, risk ve aşırı değerlemeyle ilgili olarak mevcut sistemin eksikliklerinin ele alınmasıdır. Bununla beraber, gayrimadddi varlıklar, risk ve aşırı değerlemeye ilişkin bu eksiklikler emsallere uygunluk ilkesi ile ilgili olan veya olmayan önlemler gerektirmektedir ${ }^{47}$.

\subsection{Daimi İşyeri ile Transfer Fiyatlandırması Arasındaki İlişki}

Daimi işyeri kurallarına (dijital ekonomi konuları dışında) ilişkin BEPS sorunları, daimi işyeri kurallarının teknik bir işlemiyle çok uluslu şirket grubunun bir üyesinin vergiden korunması ve ilgili grup gelirinden büyük bir pay almasına neden olurken, grubun diğer üyesine (örneğin, bir komisyoncu) fiziksel varlı̆̆ i ile vergilendirme yetki alanı arasında bağ bulunmasına rağmen düşük risk nedeniyle sınırlı kârın tahsis edildiği durumlar ile ilgilidir ${ }^{48}$. Ekim 2014 tartışma taslağı, bu taslakta bulunan çeşitli seçenekler altında daimi işyeri tanımı ve daimi işyeri eşiğine ilişkin çalışmalar ile Eylem Planının diğer bölümlerinde transfer fiyatlandırmasına ilişkin olarak devam eden çalışmalar arasındaki etkileşimlere ilişkin olarak yapılacak değişikliklerin sonucu olarak işyerinin bulunduğu Devlete tahsis edilecek ek kârların belirlenmesi ve kârın ilişkilendirilmesine odaklanan 7 inci Eylemin ön çalışması niteliğindedir ${ }^{49}$.

Eylem 7'ye ilişkin çalışmaların sonucu olarak kârın ilişkilendirilmesine ilişkin olarak bugüne kadar yapılan çalışmalar, daimi işyerinin mevcut tanımı altında tahsis edilecek kârlarla karşılaştırıldığında daimi işyeri tanımında yapılacak değişikliklerin sonucunda, bu daimi

46 OECD, "Action Plan on Base Erosion and Profit Shifting", s.19-20.

47 OECD, "Action Plan on Base Erosion and Profit Shifting", s.20.

48 OECD, "BEPS Action 7: Preventing The Artificial Avoidance of PE Status", Public Discussion Draft, 31 October 2014-9 January 2015, s.26.

49 OECD, “BEPS Action 7: Preventing The Artificial Avoidance of PE Status”, Revised Discussion Draft, 15 May 2015 12 June 2015, s.37. 
işyerinin bulunduğu Devlete tahsis edilecek ek kârın belirlenmesi üzerine odaklanmıştır. Daimi işyerinin tanımında, yapılması gereken değişikliklerin belirlenmesinde önemli bir husus olan kârların niteliklerinin neler olduğu sorusunu vurgulayan Eylem 7’nin ifadesinin nedeni de budur. $\mathrm{Bu}$ çalışma aynı zamanda daimi işyeri eşiği üzerindeki çalışma ile transfer fiyatlandırması ile ilgili Eylem Planının diğer bölümlerine ilişkin olarak devam eden çalışmalar arasındaki diğer etkileşimleri de incelemektedir. Bu ön çalışma sırasında eklemelerin yararlı olacağı birkaç alan belirlenirken, bu notta yer alan önerilerin kabul edilmesi halinde daimi işyeri ile ilişkilendirilen kârların niteliğine ilişkin mevcut kurallarda ve rehberde yapılması gereken önemli değişiklikler ise belirlenmemiştir. Ancak, BEPS Eylem Planı’nın diğer bölümleri üzerindeki çalışmanın, özellikle Eylem 9 (Riskler ve sermaye), mevcut kural ve rehberin bazı yönlerinin yeniden gözden geçirilmesini içerebileceği kabul edilmiştir ${ }^{50}$. Model anlaşma, bir ülkedeki hazırlayıcı veya yardımcı nitelikteki faaliyetler için istisnaları belirlemek amacıyla faaliyetlerin grup şirketleri arasında "bölünmüş" olduğu durumları kapsayan geniş kapsamlı bölünme karşıtı kuralları içercektir ${ }^{51}$. Tartışma taslağı aynı zamanda transfer fiyatlandırması ile ilgili Eylem Planının diğer bölümlerindeki çalışmaların sonuçlarının, özellikle gayri maddi varlıklar, risk ve sermaye ile ilgili çalışmanın dikkate alınması gerektiğini vurgulamıştır. Bu nedenle, kârın ilişkilendirilmesiyle ilgili Eylem 7’ye ilişkin çalışma, Eylem 7 ve Eylem 8-10’a ilişkin çalışmalar tamamlanmadan önce amaca uygun bir şekilde gerçekleştirilmiş olmaz ${ }^{52}$.

Rapor, şantiyelerde ve inşaat veya tesisat projeleri için daimi işyerini oluşturan belirlenmiş 12 aylık süreyi bozmak için grup şirketler arasında sözleşmelerin bölünmesine ilişkin olarak şerhin aşağıdaki şekilde güncellenmesi gerektiğini belirtmektedir ${ }^{53}$ :

- Çifte Vergilendirmeyi Önleme Anlaşmalarının kötüye kullanımının önlenmesi konusundaki (BEPS Eylem Planının 6 incı Eylemi) temel amaç testinin uygulanmasını göstermek için bir örnek eklemesi gerekmektedir.

- 12 aylık sürenin belirlenmesi amacıyla, bu zaman süresi içinde yakından ilişkili teşebbüsler tarafından yürütülen bağlantılı faaliyetler (30 günlük süreyi aşan) için alternatif bir hüküm (temel amaç testini içermeyen anlaşmalar için) önerilmesi gerekmektedir

Dolayısıyla daimi işyeri eşiği üzerinde yapılan çalışmalar ile transfer fiyatlandırması ile ilgili Eylem Planının diğer bölümlerine ilişkin olarak devam eden çalışmalar arasındaki ilişki ticari kazancın belirlenmesi açısından oldukça önemlidir.

Raporda, daimi işyerine dağıtılan kârların belirlenmesi için OECD’nin mevcut kurallarında değişiklikler gerekli olmasa da, eşik değişikliklerden kaynaklanan yeni daimi işyeri uygulaması

50 OECD, "BEPS Action 7: Preventing The Artificial Avoidance of PE Status", Public Discussion Draft, 31 October 2014-9 January 2015, s.26.

51 Deloitte, s.3.

52 OECD, "BEPS Action 7: Preventing The Artificial Avoidance of PE Status", Revised Discussion Draft, 15 May $2015-$ 12 June 2015, s.37-38.

53 Deloitte, s.3-4. 
için hangi kuralların gerekli olduğuna ilişkin ek rehberlik gerektiği belirtilmektedir. Bu rehber, finansal hizmetler sektörü dışındaki işletmelere odaklanacak ve BEPS'deki düzeltmeler maddi olmayan duran varlıklar, risk ve sermayeye ilişkin transfer fiyatlandırması rehberinde dikkate alınacaktır. Yeni rehber çalışmaları vergi anlaşmalarındaki daimi işyeri eşiğine ilişkin değişiklikleri en uygun zamanda uygulamak için kullanılacak çok taraflı bir enstrümandır ${ }^{54}$.

4 Temmuz 2016 tarihinde OECD tarafından BEPS projesinin bir parçası ve devamı olarak yapılan çalışmalar sonucunda iki taslak metin ilgililerin görüşüne açıldı. Birinci taslak metin BEPS’in 7 numaralı eylem maddesi kapsamında (iş yeri oluşumundan yapay yollarla kaçınmanın önlenmesi) hazırlandı. Söz konusu eylem kapsamında hazırlanan Ekim 2015 tarihli nihai raporda, iş yerine atfedilecek kazancın belirlenmesiyle ilgili ilave çalışmaların yapılması gerektiği belirtilmekteydi. $\mathrm{Bu}$ gereklilik kapsamında yapılan çalışmalar sonucunda hazırlanan taslak metin iki olgusal duruma vurgu yapmaktadır. Bunlardan biri komisyonculuk ve benzeri yapıların bağımlı acente olarak iş yeri oluşturması ve depoların sabit bir yer olarak iş yeri kavramı karşısındaki durumudur. İkinci taslak metin ise, 8-10 numaralı BEPS eylemleri kapsamında hazırlanan nihai raporda yer verilen transfer fiyatlandırması konularından biri olan transfer fiyatlandırması yöntemlerine atıf yapmaktadır. Taslak metnin amacı işlemsel kâr bölüşüm yöntemini, global değer zinciri bağlamında açıklığa kavuşturmak ve yöntemin uygulanabilirliğini güçlendirmektir. Bu kapsamda taslak metin kâr bölüşümünü iki farklı yaklaşım altında detaylandırmaktadır. Bu yaklaşımlar; "fiili kazançların" işlemsel kâr bölüşümüne konu edilmesi ve "beklenen kazançların" işlemsel kâr bölüşümüne konu edilmesidir ${ }^{55}$.

Eylem 7 çalışmalarının sonuçlarının uygulamaya konacağı çok taraflı enstrümanların müzakeresi için belirlenmiş son tarih olan 2016 yılı sonuna kadar gerekli olan rehberliği sağlamak amacıyla çalışmalara devam edilecektir ${ }^{56}$.

\section{Sonuç}

Küreselleşme ile ülkeler arasındaki faktör hareketlerinin hızlanması ve çok uluslu şirketlerin yaygınlaşması ülkelerin birbirleriyle ekonomik etkileşim içerisine girmelerine neden olmuştur. Bu durum özellikle mobil üretim faktörlerinin nerede kullanıldı̆̆ı ve karşılığnda elde edilen gelirin de nerede ödendiğini belirsizleştirmektedir. Ekonomik faaliyetlerin sınır ötesi nitelik kazanması nedeniyle, çok uluslu şirketler birden fazla ülkede faaliyet gösterebilmekte ve dolayısıyla birden fazla devletin egemenlik alanı içerisinde bulunabilmektedir. Bu durum çok uluslu şirketler tarafından elde edilen ticari kazançların elde edildiği yerin tespitini güçleştirmektedir. Elde edilen gelir üzerinden devletlerden biri kaynak ilkesi dolayısıyla vergi alırken, diğer devlet ikametgâh ilkesi dolayısıyla vergi alabilmektedir. Bu durum çifte vergilendirme sorununun ortaya çıkmasına neden olabilmektedir.

Deloitte, s.4.

Abdulkadir Demirci, "Uluslararası Vergi Dünyasından Haberler”, Vergi Dünyası, Sayı.420 (Ağustos 2016), s.181. OECD, "BEPS Action 7: Preventing The Artificial Avoidance of PE Status", Revised Discussion Draft, 15 May 2015 12 June 2015, s.38. 
Çifte vergilendirme konusunda uluslararası kuruluşların yaptıkları çalışmalar yirminci yüzyılın başına dayanmaktadır. Ancak değişen ekonomik yapı uluslararası kuruluşların "çifte vergileme" sorunu üzerinde çalışmasının yanı sıra "çifte vergilememe" sorunu üzerinde de çalışmasına neden olmuştur. Çünkü küreselleşme eğilimlerinin neden olduğu vergi matrahının aşındırılması ve kârın aktarılmasına ülkeler için önemli bir sorun haline gelmiştir. Vergi planlaması yaparak vergi yüklerini azaltmak isteyen mükellefler ülkelerin mevzuatlarındaki farklılıklar ve vergi anlaşmalarının yarattığı olanaklardan yararlanabilmektedirler. Mükellefler sınır ötesi ekonomik faaliyetlerde bulunurken ülkeler arasındaki vergi farklılıklarını kullanarak vergi yüklerini minimize edebilmektedir.

$\mathrm{Bu}$ konuda son dönemlerde yapılan çalışmaların önemli konularından birisi de daimi işyeri kavramı konusudur. Bu konuda yapılan çalışmalar daha çok kârın aktarılması ve matrahın aşınıdırılmasını önleyebilmek amacıyla OECD Model Vergi Anlaşması’ndaki daimi işyeri tanımının değiştirilmesine yöneliktir. Ancak daimi işyeri eşiği üzerinde yapılan çalışmalar ile transfer fiyatlandırması ile ilgili Eylem Planının diğer bölümlerine ilişkin olarak devam eden çalışmalar arasındaki ilişkiyi de göz ardı etmemek gerekmektedir. Daimi işyeri ile teşebbüsün kârları arasındaki ilişki, ticari kazancın belirlenmesi açısından oldukça önemlidir. Bu nedenle yapılan çalışmaların vergi anlaşmaları bağlamında, Türk Vergi Sistemindeki işyeri ile transfer fiyatlandırması kurallarında neden olabileceği değişiklikler ve etkilerinin yakından takip edilmesi oldukça önemlidir.

\section{Kaynakça}

CASTRO, Leonardo F. M. "Problems Involving Permanent Establishments: Overview of Relevant Issues in Today's International Economy”, http://www.globalbusinesslawreview.org/wp-content/ uploads/2012/04/1gCastro.pdf, Erişim Tarihi (20.04.2016), ss. 125-158.

ÇEVİK, Savaş, Küresel Ekonomide Uluslararası Vergileme, Palet Yayınları, Ekim 2013.

DELOİTTE, "BEPS Action 7: Preventing the Artificial Avoidance of Permanent Establishment Status", Ireland, http://www2.deloitte.com/content/dam/Deloitte/ie/Documents/Tax/BEPS\%20 Action\%207\%20-\%20Artificial\%20avoidance\%20of\%20permanent\%20establishment\%20 status\%20-\%20October\%202015.pdf, Erişim Tarihi (20.04.2016), ss.1-5.

DEMİRCI, Abdulkadir, “Uluslararası Vergi Dünyasından Haberler”, Vergi Dünyası, Sayı.420, Ağustos 2016, ss.178-183.

G20 Leaders Declaration, G2012, Mexico, http://www.consilium.europa.eu/uedocs/cms_Data/docs/ pressdata/en/ec/131069.pdf, Erişim Tarihi (16.08.2016), ss.1-15.

IŞIK, Hüseyin, Uluslararası Vergilendirme, İstanbul: On İki Levha Yayıncllık, 2014.

OECD, “Action Plan on Base Erosion and Profit Shifting”, 2013, https://www.oecd.org/ctp/BEPSActionPlan. pdf, Erişim Tarihi (10.02.2016), ss.1-46.

OECD, "BEPS Action 7: Preventing The Artificial Avoidance of PE Status", Public Discussion Draft, 31 October 2014-9 January 2015, https://www.oecd.org/ctp/treaties/action-7-pe-status-publicdiscussion-draft.pdf, Erişim Tarihi (18.04.2016), ss.1-26. 
OECD, "BEPS Action 7: Preventing The Artificial Avoidance of PE Status", Revised Discussion Draft, 15 May 2015-12 June 2015, http://www.oecd.org/tax/treaties/revised-discussion-draft-beps-action7-pe-status.pdf, Erişim Tarihi (28.04.2016), ss.1-38.

OECD, "Model Convention With Respect to Taxes on Income and on Capital", 2014, https://www.oecd.org/ ctp/treaties/2014-model-tax-convention-articles.pdf, Erişim Tarihi (15.03.2016), ss.1-44.

OECD, "OECD/G20 Base Erosion and Profit Shifting Project-Action 13: Country-by Country Reporting Implementation Package”, 2015, http://www.oecd.org/tax/transfer-pricing/beps-action-13country-by-country-reporting-implementation-package.pdf, Erişim Tarihi (29.04.2016), ss.1-42.

OECD, "Report on the Attribution of the Profits to Permanent Establishment", 2008, http://www.oecd.org/ tax/transfer-pricing/41031455.pdf, Erişim Tarihi (06.07.2016).

OECD Commitee on Fiscal Affairs, "Model Tax Convention on Income and on Capital", 22 July 2010, webdms.ciat.org/action.php?kt_path_info=ktcore.actions...view...,” Erişim Tarihi (20.04.2016), ss.1-2134.

ÖNER, Cihat, Vergi Hukukunda İşyeri, Ankara: İmaj Yayınevi, 2016.

ÖZ, N. Semih, Uluslararası Vergi Rekabeti ve Vergi Cennetleri, Ankara: Maliye ve Hukuk Yayınları, 2005.

TUNCER, Selâhattin, Çifte Vergileme ve Milletlerarası Vergi Anlaşmaları, Ankara: Sevinç Matbaası, 1974.

UBAY, Birol, "Elektronik Ticaretin Vergilendirilmesinde Avrupa Birliği ve OECD Yaklaşımları”, Vergi Dünyas1, Sayı.381, Mayıs 2013, ss.116-123.

YALTI SOYDAN, Billur, Uluslararası Vergi Anlaşmaları, İstanbul: Beta Basım, 1995. 
